\title{
A Case Role of Verbs in the Movie Script Harry Potter and the Chamber of Secret
}

\author{
Ni Nyoman Dewi Astari Putri \\ English Department, Faculty of Arts, Udayana University \\ [yesungastari@gmail.com]
}

\begin{abstract}
Abstrak
Tulisan yang berjudul "A Case Role of Verbs in the Movie Script Harry Potter and the Chamber of Secret" bertujuan untuk dapat mengidentifikasi jenis kata kerja, mengetahui struktur semantik serta kaitan antara kata kerja dan argumentnya. Data dalam tulisan ini berasal dari klausa dan kalimat dalam naskah film. Data tersebut dikumpulkan dengan menggunakan metode dokumentasi dan teknik mencatat. Data tersebut kemudian dianalisa menggunakan teori Case Grammar yang dikemukakan oleh Walter Cook (1979) dengan metode qualitatif. Hasil analisis kemudian dipaparkan menggunakan metode informal.Berdasarkan analisis yang telah dilakukan, ada tiga jenis kata kerja yang ditemukan yaitu kata kerja keadaan, proses, dan aksi. Struktur semantik dari sebuah kalimat ditunjukkan oleh case frame meliputi kata kerja keadaan, kata kerja proses, kata kerja aksi, kata kerja keadaan pengalaman,kata kerja proses pengalaman, kata kerja aksi pengalaman, kata kerja keadaan benefaktif,kata kerja proses benefaktif, kata kerja aksi benefaktif, kata kerja keadaan lokatif,kata kerja proses lokatif, dan kata kerja aksi lokatif. Selain itu, kaitan antara kata kerja dan argumentnya dalam struktur lahir/luar adalahsebagai agent, experiencer, benefactive, object, dan locative. Dalam struktur batin/dalam, kaitan antara kata kerja dan argumenya bisa sebagai lexicalized, coreferential, dan build in.
\end{abstract}

Kata kunci: case grammar, case role, struktur semantik

Abstract
This writing entitled "A Case Role of Verbs in the Movie Script Harry Potter and the
Chamber of Secret" was conducted in order to be able to identify the types of verb, to
find out the semantic structure and the case role between the verb and its cases. The
data in this study were taken directly from clauses and sentences found in the movie
script. Those data were collected using the documentation method and note taking
technique. In analyzing the data, Case Grammar theory proposed by Walter Cook
(1979) was applied by qualitative method. In addition, in order to present the data
analysis clearly and neatly, informal method was used to describe and explain the
data.The result shows that there were three types of verbs found in the movie script.
Those verbs are state, process, and action verbs. In addition, the semantic structure of
the data is shown by using case frames. The case frames of the data are basic state,
basic process, basic action, state experiential, process experiential, action experiential,
state benefactive, process benefactive, action benefactive, state locative, process
locative, and action locative verb. Besides, the case role of the datain surface structure
is as agent, experiencer, benefactive, object, and locative. Furthermore, the analysis of


deep structure showed that there are three covert case roles found in the data namely lexicalized, coreferential, and build-in.

\section{Keyword: case grammar, case role, semantic structure}

\section{Background}

A verb is considered as the most important element within a sentence. The reason is that a verb is the core or the center of a clause and sentence as it presupposes a number of participants, i.e. one, two or three depending on the semantic concern (Dixon, 1991;9). This participant is called argument. It bears a specific grammatical or semantic relation to a verb and whose overt or implied presence is required to form a wellformedness sentence structure containing that verb (Trask 1993: 20).

In semantic, the relationship between the verb and its arguments is known as case role. Each of cases within a sentence is assigned a certain role that relates to its verb. In the Case Grammar, the argument is labeled as case.Each case that occurs with a verb is matched by a semantic feature in the verb itself. According to Cook $(1979 ; 52)$ there are five propositional cases required by semantic valence of the verb. They are Agent (A), Experiencer (E), Benefactive (B), Object $(\mathrm{O})$, and Locative (L).

The relationship between a verb and its cases can be analyzed using Case Grammar theory. Cook $(1979 ; 28)$ defined it as "a system which views the deep structure of sentences as a set of relations between a verb and a series of casemarked noun phrases".

From the explanation above, it is very interesting to analyze the case role found in movie script entitled Harry Potter and The Chamber of Secret by using Case Grammar theory proposed by Cook (1979) because by analyzing case role, it is possible to find out the role played by the cases of a verb within a clause or sentence in certain events or situation.
Therefore, it gives the reader a deeper understanding about the meaning and the relation between the verb and its cases by knowing "Who did what to whom" and also "When and where". In addition, the analysis is shown by using case frame to make it easier to identify the types of verb, semantic structure and case role.

\section{Problems of the Study}

a) What types of verbs are found in the movie script Harry Potter and The Chamber of Secrets?

b) What are the semantic structures of the verbs found in the movie script Harry Potter and The Chamber of Secrets?

c) What are the case roles between the verb found in the movie script Harry Potter and The Chamber of Secrets?

\section{Aims of the Study}

a) To identify the types of verbs found in the movie script Harry Potter and The Chamber of Secrets based on the verb classification in terms of vertical dimension which consists of state, process, and action verb.

b) To find out the semantic structure of the verbs found in the movie script Harry Potter and The Chamber of Secrets that can be shown by using case frame.

c) To find out the case role played by each case in a clause or sentence found in the movie script Harry Potter and The Chamber of Secrets.

\section{Research method}

Research method may be understood as all those methods that are used in 
conducting a research (Moleong, 2009). According to Kothari $(2004 ; 7)$, research method refers to "the behavior and instrument used in selecting and constructing research technique". Therefore, it is considered as an important procedure for the validity of the research. It has four aspects, namely data source, method and technique of collecting data, method and technique of analyzing data as well as method and technique of presenting analysis.

\subsection{Data source}

The data in this study were taken directly from clauses and sentences in the movie script entitled Harry Potter and The Chamber of Secrets. It is a 2002 British-American fantasy film. The story is based on the second novel by $\mathrm{J}$. K. Rowling with same title. The reason for choosing this movie script as the data source is because it provides the relevant data for this study. There are many clauses and sentences that consist of one verb which can be used as data for this study. Moreover, this movie script provided various types of verbs.

\subsection{Method and technique of collecting data}

Documentation method was used in this study. According to Moleong (2009) documentation method is used to find out relevant data by using book, transcript, newspaper, magazine, ancient inscription, notes of a meeting, agenda, etc.This method was used because it can be made to examine and interpret something. In addition, there was no respondent or informant involved in this study because the data were collected from movie script which was downloaded from internet.

The technique that was used in this study was note taking technique by the following steps; the movie script was downloaded, the script was read carefully in order to be able to find out the relevant data, those relevant data were noted down, and finally all of the collected data were analyzed based on the theories applied in this study.

\subsection{Method and technique of analyzing data}

The collected data in this study were analyzed by using qualitative method which relies on narrative description. It means that the analysis was described in detail and was supported by the theory applied in this study.

The analysis was started by categorizing the collected data, then the surface structure of the collected data was firstly analyzed to find out the semantic structure and the overt case role, finally the deep structure of the collected data was analyzed in order to be able to find out the covert case role of those collected databy using Case Grammar Theory proposed by Cook (1979).

\subsection{Method and technique of presenting analysis}

The analysis of this study was presented in informal method. Each problem in this study was presented descriptively by words and explanation. In addition, in order to support the method of presenting the data analysis, descriptive technique was used.Therefore, the data can be explained in detail.

\section{Results and discussions}

\subsection{The analysis of types of verb}

Based on the classification ofverb in vertical dimension proposed by Cook (1979;203), there are three types of verb found in the data sourceas presented below:

\section{a. State verb}

[5-1]Madam Sprout hasa very healthy growth of Mandrakes 
(Harry Potter and the Chamber of Secret, 00:47:16).

The verb has in the data above can be categorized as state verb since it specifies that the object of the data a very healthy growth of Mandrakesis in a certain state or condition (Cook, 1979). On the other hand, the condition of the object of the data does not change as the activity has done by Madam Sprout does not affect to the object. In addition, this data is unable to take both progressive aspect such as Madam Sprout is having a very healthy growth of Mandrakesand command imperative like has a very healthy growth of Mandrakes, Madam Sprout!As proposed by Chafe (1970).

\section{b. Process verb}

[5-2]Harry freezes (Harry Potter and the Chamber of Secret, 01:36:17).

In term of verb types, the data above belongs to process verb as the verb freezes specifies that the Object case Harry undergoes a change of state or condition (Cook, 1979;63). On the other hand, the condition of Harry changes from one into another. Moreover, this data is able to take progressive aspect, has progressive meaning and the nature of sensory perception as the characteristics of process verb argued by Chafe (in Cook, 1979;62) such as Harry is freezing. In addition, this data is unable to take command imperative such as freeze Harry!.

\section{c. Action verb}

[5-3] The monster had killedsomeone(Harry Potter and the Chamber of Secret, 01:33:48).

Killed in the data above is an action verb that expresses an action done by the monster. By doing the action killed, it affects to the object of the data someone.
In addition, this data has the characteristics of action verb as proposed by Cook (1979;203). Those characteristics are able to take both progressive aspect such as the monster had been killing someone and command imperative like kill someone, monster!. Furthermore, a question proposed by Chafe (in Cook, 1979) that is used to test non-state verb is able to be answered by this data. That question is "What happened?" or "What's happening". Therefore, this data can be categorized as action verb.

\subsection{Surface structure analysis}

\section{a. Semantic structure}

The semantic structure of a certain sentence can be analyzed through case frame. It is because all of the cases in a sentence are listed in the case frame. The semantic structure of the data found within the movie script are basic state, basic process, basic action, state experiential, process experiential, action experiential, state benefactive, process benefactive, action benefactive, state locative, process locative, and action locative verb. Below are some examples: [5-4] You both receive Special Awards

for Services to the
School(Harry Potter and the
Chamber of Secret, 02:18:26).

Process benefactive verb is used to describe that a benefactor undergoes a change of state or condition with respect to a given object (Cook, 1979;65). In the data above, the verb receive needs the occurrence of Benefactive (B) and Object (O) case to accompany it. The Benefactive case of the data above is you. It is the one who gains something after doing certain action in a certain period. Special Awards for Services to the School is the Object case and the property which is gained by the Benefactor case after doing some effort. The semantic structure of the data above is $+[$ [_ B-O]. 
[5-5] We'll get youa seat (Harry Potter and the Chamber of Secret, 00:22:44).

The verb get indicates action benefactive verb. It means someone does an activity that causes the possessor gains or losses an object. On the other hand, there is a transfer of property that causes the benefactor gains or losses something. Get requires three cases in its semantic structure. The first case is we. It is the Agent case (A) or someone who does the activity. You is the second case that bears the Benefactive case (B) who gains something from the activity done by the Agent case. The third case is a seat that is also called Object case $(\mathrm{O})$. It is something transferred by the Agent case to the Benefactive case. Therefore, the semantic structure of the data above is + [ A-B-O].

[5-6] Hagrid brought mehere(Harry Potter and the Chamber of Secret, 01:46:51).

Cook $(1979 ; 66)$ defined action locative verb as "an activity involving the change of place of an object distinct from the agent". The verb brought indicates that its object changes its location due to the activity done by the subject of the data above. The activity brought requires three cases. The first case is Agent case (A) who does the action brought. In this data Hagrid is the Agent case. By doing an action brought, the Object case (O), which is also the second case, moves to a different location or place. The Object case of the data above is me that movesto the third case, that is, here. The third case is called Locative case (L) which specifies where the object change its location after an action is done by the Agent case. Thus, the semantic structure of the data is + [_ A-O-L].

\section{b. Case role}

From the surface structure point of view, overt case role is found within the data. It means that all of the cases required by a certain verb are present both in surface and deep structures. It can be as agent, experiencer, benefactive, object, and locative. Here is the example of case role analysis:

[5-7] An owl drops a letterat uncle Vernon's feet (Harry Potter and the Chamber of Secret, 00:08:30).

Based on the example above, it is known that the verb drops needs three cases to accompany it namely Agent, Object and Locative case. TheAgent case (A) an owl refers to the doer of the action drops. In doing the action dropping, there must be something dropped, that is, a letter which is also the Object case $(\mathrm{O})$ of the data. In action locative verb, Locative case $(\mathrm{L})$ is needed to describe to where the Object case is moved, that is, at uncle Vernon's feet. The case role between the verb drop and its cases is as agent, object, and locative.

[5-8] We play our game(Harry Potter and the Chamber of Secret, $01: 35: 33$ )

The Agent case (A) of the data above is we that specifies the one who do the actions play. That verb needs the occurrence of Object case (O) as something that is affected in order to arrange a complete and meaningful sentence. The Object case of the data is our game. The case role between the cases and the verb play is as agent and object.

\subsection{Deep structure analysis}

After doing surface structure analysis, it is found that there are some cases absent from the surface structure; however, they are present in the deep structure. This is called covert case role that means the case is found after doing 
intuitively judgment. Furthermore, covert case role can be lexicalized, coreferential, and build in.

a. Lexicalized case

[5-9] Madam Sprout had bottled it yesterday (Harry Potter and the Chamber of Secret, 01:53:32).

The data above means Madam Sprout had pour the Polyjuice Potions into a bottle yesterday. The Object case $(\mathrm{O})$ of the data above is it that refers to Polyjuice Potions. The Agent case (A) is Madam Sprout who does an action bottled. The verb bottled in the data above means 'put into a bottle'. The place where the Agent case puts the Object case is called Locative case (L), that is, into a bottle. Since Locative case is lexicalized into the surface form of the verb, the Locative case is symbolized as ${ }^{*} \mathrm{~L} / \mathrm{L}-\mathrm{Lex}$ in the case frame to show that the Locative case is absent from surface structure, however, it is present in the deep structure (Cook, 1979;136). Furthermore, the deep structure of the data can be described as + [ A-O-*L/LLex].

\section{b. Coreferential case}

[5-10] He reads it Harry Potter and the Chamber of Secret, 00:08:31).

Reads belongs to experiential verb. It means that there is someone who causes another experience something. In the data above he takes role both as Agent case (A) and Experiencer case (E). It is because he is the doer of the action that causes himself to experience something. The content of their experience is it which is known as called Object case $(\mathrm{O})$. Hence, the Agent case is coreferential with Experiencer case and they are written as $\mathrm{A}=\mathrm{E}$ in the case frame as they refer to the same person and get one realization in the surface structure. In addition, the Experiencer case is symbolized as ${ }^{*} \mathrm{E}$ in the case frame to show that the case is absent from the surface structure(Cook, 1979;136). Therefore, it can be written as + [_ A$* \mathrm{E}-\mathrm{O} / \mathrm{A}=\mathrm{E}]$.

\section{c. Build in case}

[5-11] Hermione wears a Slytherin robe.(Harry Potter and the Chamber of Secret, 01:20:25).

In the example above, Hermione is the doer of the action wear. She is the Agent case (A) that affects the Object case (O). A Slytherin robe is considered as the Object case which changes its location since it was wore by the doer. Generally, it has been known where a robe should be worn. It enrobes to wrap around someone's body (Locative case/L). In addition, it is only present in the deep structure. Thus, the Locative case is called build-in case and it is symbolized as *L/L Build in(Cook, 1979;136). The meaning of the example above is Hermione wears the robe to wrap her body. As a result, the deep structure analysis can be shown as + [_ A-O-* $\mathrm{L} / \mathrm{L}=$ Build in $]$.

\section{Conclusions}

Regarding to the analysis conducted in the previous chapter, there were three points presented in this chapter as the conclusion.

First, all of the data in this study can be categorized into three types of verb based on vertical dimension point of view as proposed by Cook $(1979 ; 203)$. Those verbs are state, process, and action verb.

Second, the semantic structures of the data were shown by using case frame in form of $+[\quad \mathrm{X}-\mathrm{Y}-\mathrm{Z}]$. The case frame of basic verbs are $+[$ Os] for basic state verb, $+[\mathrm{O}]$ for basic process verbs, and $+[$ A A-O $]$ for basic action verb. In experiential verbs, the case frames are + 
[ E-Os] for state experiential verb, + E-O] for process experiential verbs, $+[$ A-E-O $]$ for action experiential verb. The case frame of benefactive verbs are $+[\mathrm{B}-\mathrm{Os}]$ for state benefactive verb, $+[$ [ $B-O]$ for process benefactive verbs, and $+[$ A-B-O $]$ for action benefactive verb. While in locative verbs, + [_ Os-L] is the case frame of state locative verbs, $+[\mathrm{O}-\mathrm{L}]$ for process locative verbs, and $+[$ A $A-O-L]$ is for action locative verbs (Cook, 1979).

The last, the case role found in the data was overt and covert. In overt case role, all of the cases of the data are present both in surface and deep structure. Theovert case role between the cases and the verb itself found in the data is as agent, experiencer, benefactor, object, and locative. In contrast, covert case roles are only present in the deep structure (Cook, 1979;136). The covert case roles found in the data are lexicalized, coreferential, and build-in.

\section{References}

Chafe, Wallace L. (1970). Meaning and the Structure of Language.The University of Chicago Press, Chicago.

Cook, Walter A, S. J. (1979). Case Grammar: Development of the Matrix Model (1970-1978). Georgetown University, Washington.

Dixon, R.M.W. (1991). A New Approach to English, on Semantic Principles. Oxford University Press, New York.

Kothari, C.R. (2004). Research Methodology Methods and Techniques. New Age International Publisher, Jaipur.
Moleong, Lexy. (2009). Metodologi Penelitian Kualitatif. Remaja Rosdakarya, Bandung.

Trask, R. L. (1993). A Dictionary of Grammatical Terms and Linguistics. New York, Routledge, London. 